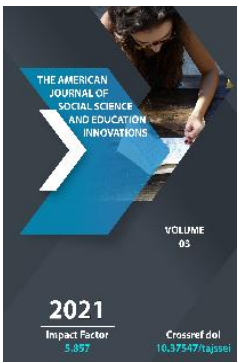

\title{
Depiction Of Aesthetic Categories In The Art Of Maqom
}

\author{
Zulxumor Sidamatovna Nurullaeva \\ Doctoral Student, Department Of Ethics And Aesthetics, Faculty Of Social Sciences, National \\ University Of Uzbekistan Named After Mirzoulugbek, Uzbekistan
}

Journal Website:

http://theamericanjour

nals.com/index.php/taj

ssei

Copyright: Original content from this work may be used under the terms of the creative commons attributes 4.0 licence.

\section{ABSTRACT}

This article discusses the expression of aesthetic categories in the art of maqom. Beauty, majesty, tragic fantasy are the reflections of aesthetic categories in the statuses of Buzruk, Navo, Segoh, and the ideas of Eastern and Western philosophers have been widely used in this regard. In addition, the psycho-emotional factors of music affecting the human spirit are explained. For example, the sevensounding structures from Ushshak to Isfahan evoke a range of emotions in the process of forming music, from strength and courage to the joy of delicate enjoyment, while the other six evoke sadness and lack of will.

\section{KEYWORDS}

Aesthetics, category, beauty, splendor, makom art, music lad, frequency, love, happiness.

\section{INTRODUCTION}

The science of aesthetics has its own rich and complex categories, which are characterized by the following concepts. These are beauty, ugliness, splendor, humility, tragedy, humor, fantasy, and miracle. Categories are a specific manifestation of the aesthetic assimilation of the world in each of the spheres of social existence, human life - production, labor and socio-political activity, attitude to nature, culture, life, and so on. In each art form, these categories play a key role. 


\section{MAIN PART}

The main categories of aesthetics are also reflected in the art of maqom, from the main categories that are clearly visible; beauty is the categories of glory, tragedy. They serve as an important factor in sharing the aesthetic pleasure of a person in the art of maqom. In the art of maqom, the harmony of colors, words and music help to feel the beauty, splendor and tragedy (musical draturgy [1, 105], to enjoy it aesthetically. (There may be fantasy in the aesthetic imagination of the perceiving person). Ibn Sina (980-1037) believed that the pleasure derived from music was from the spread of musical harmony in space, from the alternation of curtains. In music, it says that it is not the sound itself that matters, but how it is produced, that is, we are aroused by the pleasant or unpleasant sensation not by the sound itself, but by the way it is produced. The origin of music, on the other hand, is associated with the richness of human speech: the voice decreases when flattered, the voice sounds firm when spoken arrogantly, and so on, i.e., the music imitates the human mood. The scholar also follows in the footsteps of Farobi in terms of beauty. In his view, physical beauty is directly determined by the beauty of the soul.Ibn Sina affirmed the hadith that beautiful beauty is in good composition and that perfect harmony and order give a person a pleasing appearance and delicate qualities, while at the same time there is a dialectical relationship between beauty and ugliness. emphasizes that the verb can be ugly because of its inner aspects. The philosopher believes that the reason for this is not in the lack of harmony in the original human-natural composition, but in a state which arose as a result of either an external accidental influence or an internal character $[2,71]$.

RESULTS AND DISCUSSIONS
This means that the art of music is closely related to the art of public speaking. Glory is primarily associated with the perfection of speech in the art of music. The majestic sound of the letters depends on how high the performer's speech is. Glory can also be seen in the vocal part of the status quo that was previously created in the art of oratory. Strength, scale, composure. Farobi examines the types of speech from a logical point of view and says that poetic speech is an absolute lie, sophistic speech is mostly false, rhetorical speech is both false and true, dialectical speech is mostly true, and proof (apodictic) speech is absolutely true. The fact that poetic speech is called an absolute lie seems to melt at first $[2,70]$.

One of the factors that gives aesthetic pleasure in the art of maqom is its fret system. The works executed in the XIII-XVII centuries form the basis of maqom ways. The very notion of "lad" in statuses also has a great deal of emotional impact. These moods also serve as a spiritual expression of the ways of status [3, 134]. Lad - tonality is the status of this or that melody, that is, the expression of the path of movement [3, 49]. Aristotle described in detail the musical modes that change the psyche. Music in one mood can make a person feel compassionate and gentle, while in another it can cause nervousness or excitement. Thus, the music in the Dari, Phrygian, and Lydian scales had a positive effect on one's spirit and health, while the music recorded in other scales was recommended not to reach the ears of the younger generation.

Other major and minor types of lads, which form the basis of the music of the peoples of Central Asia, can also be found. Lad associations are important factors in determining the level of development of folk music. They not only form the basis of the melody of the melody, but also have their own independent meaning. When played on a musical instrument, the fret associations used 
in music practice give a person a different mood.Here, too, it must be borne in mind that the melody is closely connected with the fret. Authors of medieval musical treatises have noted that sets, especially the status and subdivisions that belong to them, have a special feature (emotional) power that affects a person's feelings. The nature of their emotional impact is a factor that reflects past musical practices [3, 90].Thus, maqoms are also evidence of the high level of musical culture in the East and especially in the peoples of Central Asia. The nature of their influence on the human soul has been repeatedly mentioned by musicians of Farabi, Ibn Sina, Saifuddin Abdulmumin, Sherazi, Jami and the last period (XVI-XVII centuries) [3, 134135].

Hence, it is undeniable that the feelings that status lads give are also directly related to aesthetic carousels. Zero aesthetic categories are the main subjects of aesthetic science.

The category of glory differs from the glory in art, society, and nature. Glory in art is expressed through artistic form and content. Glory awakens in man such feelings as pride, arrogance, majesty. These feelings enter the human heart directly through the same music. While the status of Buzruk reflects the creation of the whole being, its ladi gives a glorious feeling as if it were a sign of the emergence of the universe. Man attains spiritual essence through glory, or is united with God.

In Jami's Tractat o muzyke, he discusses the effects of moods on human emotions. In that play, Buzruk's status is described as representing sorrow and grief. From an aesthetic point of view, Buzruk status is more likely to be a category of glory. Because Buzurg comes in a big, great sense and means a great status. Even in its Shashmaqom form, it contained many melodies and songs [3, 96]. In other words, size also plays a big role in the sense of glory, according to the philosopher Abdullah Sher.

That is why the German philosopher Schopenhauer interprets the art of music as the most important art in human life. Music can live to some degree, even if the world does not exist at all, by completely denying the world of events, with the exception of ideas. Other art forms are not capable of this. The effect of music is so strong that it awakens in the listener, like the will, not the idea of joy, sorrow, etc., but themselves [2, 123]. He emphasizes that.

From this point of view, status has become a part of our lives. It should be noted that Lutfi, as a ghazal writer, skillfully combined the principles and methods of folk oral art with the established literary and aesthetic traditions in Eastern literature. For this reason, in his poems, national sentiments radiate, and the image of human pain, harmony, sorrow and joy has a unique impact. Not only in his ghazals, but also in his poems of other genres, such as rubai, tuyuk, qita, fard, Lutfi sang a sense of sophistication, the thoughts and feelings of people of high taste and level intelligent and life-loving people. The status of Sarahbori Buzruk, which begins with Lutfi Ghazali, is a shining example of this.

The status of Navo reflects the winner of a person's youth full of love, that is, the love of a lover for his lover is formed on the basis of a beautiful melody. Beauty is an aesthetic category with the highest aesthetic value, which describes the phenomenon in terms of perfection. Various features of beauty have been developed in the history of culture. Beauty is the harmony, symmetry, rhythm, proportionality, purposefulness inherent in things in the world, as well as the measurement of sound and color-light relationships that characterize the appearance of events, and so on.These definite feelings of beauty could go on forever, for they belong to empirical things. The main question that 
worries thinkers of all times and nations is what is the nature of beauties? And here a number of the most characteristic approaches can be identified. 1. The objective nature of beautiful things. This approach to beauty was formed in the earlier Greek natural philosophy, where it was interpreted as a beautiful universal harmony, the beauty of the universe, the Cosmos.This interpretation of beauty is repeated in one form or another in pre-Marxist materialist aesthetics, in the aesthetics of French enlightenment. For them, beauty is a natural feature of nature, such as weight, color, size, and so on $[4,96]$.

First of all, there is a volume in the maqom, which includes more than 250 melodies. The tunes also include their own 11 minutes and more. According to Eichhorn's research, Nasrullah is so large that not everyone can perform it to the end [5, 140-141]. He put forward the idea that.

Ghazali takes music very seriously. He describes it as an art form essentially related to divinity. According to al-Ghazali, music is a blessing from the afterlife, the world of the unseen and the angels, so it is a non-rational spiritual-aesthetic phenomenon hidden from the human eye and mind, invisible to the naked eye and incomprehensible to the mind. In a word, it refers to the eternal world, the divine world. The importance of music is that it serves as a means of reaching God for the human soul as a harmony of the divine spirit. After all, the whole universe itself is the embodiment of harmony and tone. Therefore, in Ihya ul-Ulum ad-Din, al-Ghazali writes about music as follows: It is like a fire in iron and stone. When an iron strikes a stone, this flame is a spark, and as it falls to the ground, the music of a pleasant rhythm moves the heart and brings it into a state that excites the human will.This condition is manifested in the manifestation of harmony with man in the socalled divine universe. The world of beauty is the world of beauty and sophistication. The basis of beauty and sophistication is the harmony of the parts. And all harmony is a manifestation of the beauty of that world, for all the subtlety, beauty, and harmony that exists in this emotional world is the product of that world's sophistication and beauty. Therefore, rhythmic and melodic sounds, while obeying the law of conformity, at the same time become similar to the miraculous sounds of the world, and as a result are sealed in the heart, soften the heart and arouse the desire to listen in it.Statuses are one of the factors that awaken this very divine harmony.

In general, music in Ghazali's interpretation is an aesthetic phenomenon of both divine and human nature, and a peculiar type of cognition; it is a type of art that serves man, on the one hand, to know God, and, on the other hand, to realize himself. There are three types of ghazal music, or rather, three types of it: 1) for entertainment; 2) for enjoyment; 3) states that it can be used to fall into a state of state.Entertainment, music that is perceived as time-conscious, is usually light-hearted, and in some cases causes a certain amount of spiritual damage with its lustful, unthinking nature. The music, which is perceived for pleasure, immerses the soul in either joy or sweet sorrow, and encourages man to think and observe in the barbarian of pleasure. Ghazali understands music as the most powerful type of music, which can bring a person to a state of state (punishment) and, as a result, has the power to connect him with the divine world at every moment.Through such music, the dervish discovers a divine moment for himself, and throughout the melody is given entirely to the beauty of Allah. At the same time, Ghazali insists not to confuse music and entertainment with recitation, and not to confuse recitation with singing [6]. The maqoms consist of melodies and songs that al-Ghazali emphasizes, which bring a person to a state of state. O.Ibragimov elaborated on this theory in his works.

Sound structures, which have "foundation / root" status, correspond to certain emotions 
in the psychoemotional spectrum. The first group combines strength - courage entertainment, the second is intertwined only with the joy of elegant pleasure, and the third is a sign of sorrow - a lack of will. Psychoemotional states move in a sequence from positive to negative, and are interpreted by Safi ad-Din Urmavi only in terms of the correspondence needed for a poetic text, which enhances the effect of musical tones. If the seven vocal structures from Ushshak to Isfahan evoke a range of emotions in the process of forming music, from strength and courage to the joy of delicate enjoyment, the other six evoke sadness and lack of willpower. Thus, the psycho-emotional state is revealed between these joys and sorrows, but at the same time they are not tied to the system of lad in Aristotle's theory, but are understood as a period of procedural transition from one to another.As understood in Western European theory, here the emotional movement from feeling power to joy and sadness to lack of will is not related to the relationship of consonance and dissonance (in themselves or in the context of musical action). It is associated with a sense of enjoyment, and in practice it is a melodic movement that carries out relationships in the process of transitioning from one spectrum of these emotions to another.

Whether these emotional features are fully consistent with the above-mentioned sound sequence names in modern musical traditions of maqom art is an important question that needs to be studied separately, as their range composition and corresponding emotional impact are sometimes hidden behind common sound structures. As mentioned above, the less well-known (or completely unknown) the study of the emotional component of status in musical pamphlets, the more important it is: harmonic lines, revealing the emotional process can only point to one of the local traditions of maqom art, because traditions themselves and is extremely different in description.
Thus, from the thirteenth century onwards, in the genre of "pamphlets on music," the sound structure is no longer in accordance with the narrow sound of the status (curtain), as before, as the sound structure shifts to another. It is the intricately organized meaning of the status quo - the emotion that grows the content of every piece of music in the genre under consideration.

The understanding of aesthetic pleasure as a transition that connects the opposing psychoemotional states of the soul was described in works on music in the twelfth century, and from a scientific point of view this view has not changed. This is put forward by Fakhr adDin Razi (1149-1209), who believes that pleasure depends on the process of transition from one state of mind to another. "... the difference of sounds is the difference of mental states, and this ultimately gives pleasure to the soul, for in it every condition is not always pleasant, but it does not disappear, but is renewed."For this reason, we can say that the art of maqom has an ontological status as long as it reflects the state of human inner experiences. They can be called psychoemotional, filling the hearts and affecting the heart and mind. (XVI-XIX centuries) Persian musical treatises on poetry revealed the understanding of the hidden meanings of status [7, 153-154].

Many ancient writers, such as Democritus and Plato, provided ample evidence that music affected the human psyche: The Epic of Odyssey depicts the healing of a bloody wound under the influence of music, and Lycurgus, the very fierce Spartan ruler, created music for his armies.

In ancient China, music was a symbol of order and civilization, it was considered the most important means of education and was included in the list of disciplines that must be studied.It is known that Confucius himself (VI century BC) played the Sin. In India, ancient physicians used music as a means of healing. 
In the Middle Ages, the psychology of music in the Near and Middle East developed in the works of such great thinkers as Farobi, Ibn Sina, Jami, Maraghi, Kavkabi. For example, Farobi (873-950) wrote in The Great Book of Music about the great importance of music in human psychology and the spiritual world. Music can make people happy, joyful, soothing, thought-provoking, calming, refreshing, and at the same time sleepy.Ibn Sina (980-1037) said that music has a healing effect on the body as well as the soul. He studied music from both a physiological and a psychological perspective. Abdurahman Jami (1414-1492) in his "Risolai musiqa" also thought that the perception of intervals, their melodic and harmonic structures are consonance (pleasant) and dissonance (unpleasant) [8, 7-8-9].

The German scientist Schumann was the first to measure the frequency of vibrations of the earth. These vibrations provoke internal vibrations (emotions) in humans. It has been scientifically proven that when a person's inner feelings are measured, each emotion has its own vibrational frequency. Accordingly, grief ranged from 0.1 to $2 \mathrm{GHz}$, fear from 0.2 to $2.2 \mathrm{GHz}$, grievance from 0.6 to $3.3 \mathrm{GHz}$, anxiety from 0.9 to $3.8 \mathrm{GHz}$, hatred from 0.6 to $1.9 \mathrm{GHz}$, pain from $1.4 \mathrm{GHz}$, arrogance from $0.8 \mathrm{GHz}$. , pride 3.1Gts. Generosity 95Gts, gratitude $45 \mathrm{Gts}$, heartfelt gratitude $140 \mathrm{Gts}$ and above, love 50Gts, love all the people in the world, creatures $150 \mathrm{Gts}$, unconditional, being, glorious love, 205Gts [9].

So, you have to listen to the vibrating music that brings a person to the "High Self". For example, listening to music called $963 \mathrm{Gts} \mathrm{God}$ Frequency helps everyone to see God and feel that they are also a part of God. In his ontological system, al-Farabi considered the First Being (God) to be the most perfect. "The beauty, splendor, and splendor of the whole being is to understand the existence of man in the best possible way possible and to achieve perfection. His beauty surpasses any beauty in the bearer of every beauty" he emphasized that $[10,92]$.

432 Gts Happiness Harmony Harmony Frequency It is recommended to listen when a person is in a depressed mood, $528 \mathrm{Gts}$ Healing frequency, $741 \mathrm{Gts}$ Aura cleansing, 888 $G$ ts frequency music enhances love in a person $v \mathrm{x}$. In particular, the frequency of human exposure to Maqom melodies is $432 \mathrm{Gts}$.For example, Ushshak, Buslik, Navo maqoms and Mohur, Nihovand branches give courage and bravery. These attractive, melodic maqom tracks, according to sources, were more popular in Central Asia. True, Iraq, Isfahan maqoms and voices Navruz, Gardonia, from the branches Panjgoh and Zovuli are delicate, pleasant maqom ways, giving a person a peaceful, cheerful mood. Buzurg, Zirafkand, Rahovi, Zangula maqoms, Gavasht and Shahnoz voices, Gissar, Humayun, Mubarqa, Rakb, Saba, Bastai Nigor, Navruz arab, Ruyi Iraq branches represent grief, mental exhaustion, pain.Hijaz, Husseini from the maqoms, Moya, Salmak from the voices, Nuhuft from the branches, Navruz Bayoti, Dugoh, Uzzol, Avj, Javzi, Nayriz from the branches evoke both joy and sorrow [3, 135].

\section{CONCLUSION}

The beauty of music is measured by the fact that it refreshes the human psyche. The art of music illuminates human life with its beauty. No art form can directly and strongly affect human emotions like music. Music is a powerful tool that nurtures the spiritual world of human life. Without music, it is difficult for a person to feel the beauty of the world, its feelings, its spiritual values. Classical music is the pinnacle of the art of music, a type that has stood the test of time.Over the centuries, fans of classical music have never diminished. From the world of great classical music, everyone can get spiritual nourishment for themselves. Statuses have the power to express a person's noble qualities, feelings and emotions. 
The immortal musical treasure of our people the genre of maqom - occupies a special place in the musical heritage of Uzbek and Tajik people. Statuses are works of high artistic and aesthetic power. Shashmaqom serves the various artistic and aesthetic needs of our people, and even meets their cultural needs at folk festivals, weddings and celebrations.Suffice it to mention the Navo, Dugoh, Segoh and Iraqi maqam tracks, which have been played on trumpets. From a religious and philosophical point of view, status is the perception of the world through music; the world of life impressions, concepts, symbols and images of high aesthetic value; was a symbol of the infinite beauty and proportion of the soul. The shape of a circle, one derived from the other and all connected to the end of the interconnected head - the symbol of beauty, perfection - is a common sign (symbol) of status thinking.

\section{REFERENCES}

1. Aykhodjaeva Sh. Maqom taronalari (genre features, performance traditions). Dissertation for candidacy. 2008. - $105 \mathrm{p}$.

2. Abdulla Sher. Aesthetics. - Tashkent: Uzbekistan, 2015.

3. Ishaq Rajabov. Maqomlar. - Tashkent: San'at, 2006.

4. Radugin A.A. Aesthetics. Study guide. - Moscow, 2000.

5. August Eichhorn. Musical and ethnographic materials. - Tashkent: Academy of Sciences of the Uzbek SSR, 1963.

6. https://khdavron.uz/kutubxona/islomiyadabiyot/tasavvuf/abdulla-shertasavvuf-gazzoliy-vagozallikfalsafasi.html.

7. Conceptualization of music in the Abrahamic traditions. (Collective monograph) / Resp. ed. doc. art history G.B. Shamilli. - Moscow: State Institute of Art Studies, 2018.
8. Textbook of the State Conservatory of Uzbekistan MUSIC PSYCHOLOGY. Tashkent: "Music", 2005.

9. https://www.inter-

nauka.com/news/891--vibracionnyjechastoty-mozga-emocij-i-matushkizemli/.

10. Dzhumaev A. Questions of Musical Aesthetics in the Works of Middle Eastern Scientists of the 9th-12th Centuries. (Dissertation) - Tashkent, 1981. 